\title{
Stationssamhället: det moderna Sverige i ett nötskal
}

\section{Av Börje Björkman, doktorand i historia}

\author{
Länk till presentation av Börje Björkman
}

Jag steg på tåget i Alvesta.

Det har jag säkert gjort hundra gånger förut.

Jag är ofta påstigande i Alvesta.

Det är i själva verket jag som är den påstigande i Alvesta.

I dystra ögonblick får jag för mig att livet, och särskilt då mitt liv, är en ständig upprepning. Varför ska jag jämt och samt kliva på tåget i Alvesta? Varför kan jag inte hitta på något roligare? Varför åker jag inte till Kanarieöarna?

Orden är Jolos - journalisten och författaren Jan Olof Olsson - och saxade ur ett tidningskåseri från 1960-talet. Alvesta är nog idag mest känt som en kommun med station i hjärtat av Småland, som en plats man passerar mellan Stockholm och Malmö. Åtminstone så långt är nog alla med. Men vad som möjligen inte är bekant för alla och envar är att Alvesta tillkommit just som en följd av Södra stambanans sträckning söderut och att platsen därför har en hel del gemensamt med ett antal andra små eller medelstora orter. Alla är de s.k. stationssamhällen, en ortstyp som växte fram i samband med järnvägarnas utbredning från mitten av 1800-talet. På platsen för dagens Alvesta fanns tidigare endast ett par gårdar. En bit därifrån låg Aringsås kyrka med vidhängande kyrkby av ordinärt småländskt snitt.

Det var alltså först med järnvägens ankomst som Alvesta blev en kommunikativ knutpunkt men sedan dess har otaliga resenärer stigit av tåget i Alvesta. Där har de stått på perrongen en stund - precis som Jolo - och väntat på de magiska orden “...tåg mot...ankommer strax på spår..." bara för att en stund senare ha fortsatt sin resa, antingen längs den nord-sydliga stambanan eller den ost-västliga 'Kust-till-kust-banan'. I princip har nog nästan alla nu levande svenskar åtminstone någon gång åkt tåg och just därför har de också en åsikt om orter som Vislanda, Nässjö, Hässleholm, Töreboda eller Tranås - alla har de en tillkomsthistoria snarlik Alvestas. Och vem har väl inte, som Jolo, stått på en perrong någonstans i Sverige och undrat över 'varför just jag måste stå just här i denna gudsförgätna håla' - vilket inte nödvändigtvis behöver betyda just Alvesta - och svurit över tåg som varit försenade. Alltsammans naturligtvis i skarp kontrast till de bofasta som, när de väl vant sig, säkerligen har trivts bra på dessa orter. För dem har försenade tåg istället kunnat vara en inkomstmöjlighet, om inte annat så bara för en kopp kaffe.

Kort sagt: alla har vi någon gång stött på det svenska stationssamhället. Om vi inte har bott där själva så har vi iallafall bytt tåg eller passerat igenom någon gång i livet: dessa hybrider mellan stad och land tycks på något sätt innehålla allt och ingenting, helt och hållet beroende från vilket håll man ser på dem. Åsikterna om dem - särskilt från en resandesynpunkt - är inte sällan negativa. Ingen gillar väl att vänta eller att bli försenad! Dock kan de naturligtvis skifta betydligt, från den bofaste ortsbons upplevelse av, exempelvis, Vislanda som världens navel från vilken man aldrig skulle kunna tänka sig att flytta, till den tillfällige av- eller påstiganden som direkt ogillat platsen därför att det enda man skulle vilja göra där är att komma vidare så snart som möjligt!

En sorts hatkärlek till platser som Åseda, Braås, Traryd, Hyltebruk och Ryssby är heller inte ovanlig. Även detta skymtar hos Jolo som i flera artiklar och kåserier försökt fånga stationssamhällets själ, dess underliga karaktär av mellanting i nästan alla bemärkelser. Just 
småländska stationssamhällen är för övrigt väldigt vanliga i Jolos texter varför man nästan leds till att tro att småländska perronger och järnvägshotell varit som gjorda för filosofiska livsbetraktelser.

Nå, så långt skall man nog inte sträcka sig ens i tanken - vilket inte hindrar att 'det svenska stationssamhället' som fenomen, och särskilt sett med en historikers ögon, rymmer väldigt mycket av vår moderna svenska historia. På flera sätt utgör stationssamhället en sorts ytterligheternas korsning där mönster och traditioner från när och fjärran, från stad och landsbygd, har blandats på ett mycket konkret sätt: kulturellt, ekonomiskt, socialt, politiskt och varför inte arkitektoniskt och ideologiskt.

Om vi för ett ögonblick går tillbaka till järnvägarnas barndom, så utgjordes ett viktigt skäl för deras anläggande, inte minst vad gäller den statliga delen av nätet, att man ville förbättra transportmöjligheterna för industrin. Via järnvägarna skulle den till stor del landsbygdsbaserade industrin kunna utvecklas och knytas samman i ett nationellt nätverk. Järnvägarna blev samtidigt en viktig del i byggandet av det moderna Sverige och i skapandet av en nationell identitet. Med hjälp av järnvägarna fördes också den stora folkströmmen från landet till staden, med järnvägarna 'koloniserades' Norrland. Med de frustande ångloken reste de förväntansfyllda emigranterna mot sina blivande hemorter.

På samma sätt blev järnvägarna viktiga för att sprida idéer och ideologier. Det var i de små stationssamhällena som folkrörelsernas agitatorer klev av, antingen för att just där förmedla sina tankar eller för att resa vidare till mer oupplysta och ännu järnvägslösa bygder.

Nykterhetsrörelsens spridning och utbredning i Kronobergs län är ett gott exempel på detta, något som mycket konkret kan beskrivas med IOGT-logen Femårsminnet i Ryssby. Namnet minner om att det vid grundandet av logen gått fem år sedan järnvägens ankomst!

En del av dessa stationssamhällen formligen exploderade av folk och initiativkraft ty hit flyttade landsbygdens unga i ett första skede av sekelskiftets urbaniseringsvåg och invid stationerna slog sig också företagarna ned. Kanske skulle man kunna säga att det i dessa orter växte fram en särskild sorts företagssamhet vilken i sin tur bottnade i att alla (eller åtminstone nästan alla) invånarna var nyinflyttade, till en plats där möjligheterna ännu överskuggade svårigheterna och där ännu blott ett fåtal vägar till förändring hade hunnit stängas. Kort sagt: i det lilla stationssamhället tycktes allt vara möjligt. Allt kunde göras och fort kunde det gå. Åtminstone delvis kan detta förklara varför man om det lilla stationssamhället Åseda år 1918 kunde skriva att detta visserligen var "en bygd i mörker“ men att samhället ifråga blivit "uppbyggt med amerikansk fart." Ett sorts Vilda Västern i miniatyr med andra ord. Detta sista sagt med mer än en underton, ty även arkitektoniskt fanns det under 1920- och 30-talen drag av Amerika i det kronobergska Åseda. På fotografier från den tiden finns byggnader vilka man kan misstänka ha uppförts av antingen hemvändande emigranter eller av någon med emigrerade släktingar som brevledes fått reda på hur man byggde och bodde 'over there'.

Med stationssamhället sprängdes också den traditionella beskrivningen av svensk landsbygdsbebyggelse ty den gamla 'sanningen' med kyrkan mitt i byn var knappast särskilt självklar längre. Byn, eller rättare sagt bebyggelsen, flyttade ibland bokstavligen från kyrkan till stationen. Ett gott exempel på detta kan vara Grevie i nordvästra Skåne eller varför inte - återigen - Alvesta i det inre av Småland där stationen lades några hundra meter från sockenkyrkan och där man allt mindre talade om Aringsås och allt mer om Alvesta. All den nya verksamheten förlades till spårens närhet.

Vidgar vi perspektivet något så kan man samtidigt säga att med stationerna och de uppväxande nya samhällena flyttade även det nya, 'moderna', samhället ut på landsbygden i en mer påtaglig form än tidigare. Att få en järnväg länkad till sin bygd innebar att de boende länkades till det urbana samhällets livsformer, vilket i sin tur måste ha betytt såväl reella som tankemässiga kollisioner av vilka problemet med olika tidsuppfattningar nog var en. Centralt i resonemanget står uttrycket 'lokal tid' vilket vi idag bara använder när vi åker utomlands och kanske när vi hör nyhetsrapporter från någon ort på andra sidan jordklotet. 
Före järnvägarna var detta emellertid en realitet även inom rikets gränser ty varje enskild ort hade i princip sin egen tid. Tiden var verkligen 'lokal' då man i järnvägens barndom angav en orts läge inte bara som ett antal kilometer från en större ort utan även som si eller så många minuter från samma ort. Med järnvägarnas utbredning knöts lokalsamhällenas 'olika' tid samman till en enhetlig 'nationell tid', vilket på landsbygden - dvs utanför städerna, alltså inte bara utanför Stockholm - måste betecknas som en smärre tidsrevolution. I stationssamhällena bör denna process ha blivit i allra högsta grad påtaglig, eftersom det egna lokalsamhällets tidsuppfattning här måste ha konfronteras särskilt med den nya - dvs storstadens - tiden. På något sätt måste detta ha inneburit att det under en, visserligen kort, övergångsperiod måste ha funnits två gällande tider inom en och samma ort! Hur hanterade man sådant?

Man skulle kunna fortsätta beskrivningen av stationssamhällets konturer och betydelse i den lite större svenska samhällsutvecklingen en bit till, men detta kan kanske räcka för att visa på ämnets möjligheter som tanke- och forskningsobjekt. Även om det idag finns ansatser till forskning - en andra konferens kring "Det nordiska stationssamhället“ hölls vid Högskolan i Växjö i april 1998, med deltagare från såväl Sverige som Danmark - så har vi i Sverige hittills inte gjort så mycket för att uppmärksamma eller utröna betydelsen hos de många små och halvstora orterna mitt emellan stad och landsbygd.

Frågan är varför man inte upptäckt dem tidigare, ty stationssamhället rymmer på något sätt hela industrisamhällets historia, såväl dess början som dess slut och såväl vinnare som förlorare. Ser vi till svensk historisk forskning framstår det som mycket tydligt att man antingen medvetet bortsett från eller helt enkelt glömt de små och medelstora orterna. Grovt räknat har man antingen sysslat med städerna (och framförallt de större) eller den rena landsbygden. Småsamhällena - stationssamhällen, köpingar, municipalsamhällen lyser mycket ofta med sin frånvaro.

Särskilt tydligt - och tråkigt - blir detta när vi kommer in i efterkrigstidens Sverige, dvs till den stora urbaniseringens och den intensiva industrialiseringens svenska tidevarv. Detta sammanfaller ganska väl med stationssamhällenas nedgångsperiod. Under 1960- och 70talen stod det klart att tiden hade hunnit ifatt, sprungit om, ja i en del fall att den mer eller mindre helt runnit ut för dessa ofta 'enfunktionsorter'. Plötsligt var det enda som gällde för stationssamhällena att överleva, att finna en ny funktion istället för att 'bara' vara den omlastningsplats för folk och gods som man startat som. Resultatet känner vi: några klarade sig medan andra gick under, de helt enkelt tynade bort i takt med att järnvägslinjerna lades ned, i en process som emellertid i efterhand gör det ganska lätt att skilja ut vinnarna - dvs överlevarna - från förlorarna.

Till vinnarna hör naturligtvis de orter som 'lyckades', i betydelsen att de fortsatte att växa och som kanske till och med hann bli städer (som Nässjö och Hässleholm) samt de orter som faktiskt lyckades ersätta järnvägs-och-stations-beroendet med någonting annat. Till förlorarna räknas följaktligen sådana orter som inte lyckades hitta någon ny plats i solen, dvs egentligen hela skalan från dem som visserligen börjat växa men som sedan av någon anledning stagnerade - som kanske Tenhult, Urshult och Ryd - till dem som så småningom mer eller mindre har upphört att vara ett 'samhälle' - som kanske Målerås och Fagerhult. Idag vet nog bara ett fåtal var de sistnämnda är belägna.

Förklaringarna till varför det gick som det gick, varför vissa överlevde men inte andra, är säkerligen många - kanske lika många som det finns eller funnits stationssamhällen. Och även här handlar det både om aktörer och strukturer, om ekonomi och konjunktur, om lokal eller möjligen regional politisk kultur, om personlig initiativkraft och kollektiv identitet eller möjligen avsaknaden av något av det nyssnämnda. Kanske har det av stationssamhället blivit en industriort i sig själv, kanske har man övergått till att vara ett 'komplement' i form av en sovstad till någon större ort, vilket ibland till och med medfört att man fått offra sina främsta karaktärsdrag.

Det sistnämnda gäller i hög grad för den station där vi startade: Alvesta av idag kan 
mycket väl karakteriseras som en sovstad till Växjö. Där tvingades (?) man av tekniska skäl att riva den enda riktigt unika byggnation man hade, nämligen den gångbro i trä från sekelskiftet, som sträckte sig från stationsbyggnaden över spåren och till den bortersta perrongen. Sådana fanns bara ett par stycken i hela landet och möjligen var detta den sista. Varför den revs? Jo helt enkelt därför att man ville säkra Alvesta som en plats på jorden där dagens tåg - X2000 - skulle kunna passera och stanna även imorgon. För detta krävdes ombyggnad av stationsområdet och därmed föll även gångbron.

Intressant i fallet Alvesta är samtidigt att man ännu idag så starkt identifierar sig som ett stationssamhälle. Redan kommunvapnet innehöll visserligen ett hjul med vingar men idag har man fortsatt på samma tema på kommunens websida. Till skillnad från Hässleholm, Katrineholm, Nässjö m fl nämnda stationer av samma ålder och karaktär har man i Alvesta helt låtit kommunens virtuella ansikte domineras av järnvägen: Förutom att surfaren möts av kommunvapnet visas också en bit av stationshuset samt främre delen av ett X2000-tåg. Det sistnämnda med nosen riktad norrut, dvs mot Stockholm. Under bilden finns orden "Du är på rätt spår..." och till vänster finns de obligatoriska länkarna till andra sidor: just här är de utformade som räls och syllar.

Åtminstone vad gäller själva järnvägen tycks alltså Alvesta ha funnit vägen in i framtiden. Man har överlevt som samhälle och får väl därför räknas till stationssamhälleskategorins vinnare. I varje fall är det som ett sådant man fortfarande ser på sig själv.

Tids- och rumsmässigt är jag samtidigt tillbaka där jag började. Frågan är vad som kan passa bättre att avsluta med än ytterligare ett Jolo-citat:

"Smålands järnvägar och stationer har gått $i$ vår själ.

Vi är alla påstigande i Alvesta."

\section{(C) Börje Björkman}

